\title{
Effect of Apricot Stone Activated Carbon Adsorbent on the Removal of Toxic Heavy Metals Ions from Aqueous Solutions
}

\author{
Abeer El-Saharty ${ }^{1, ~ *, ~ S h a i m a a ~ N a s s e r ~ M a h m o u d ~}{ }^{2}$, Ahmed Hashem Manjood ${ }^{2}$, \\ Adel Abdel Hady Nassar ${ }^{1}$, Abdel Moneum Ahmed ${ }^{3}$ \\ ${ }^{1}$ Marine Chemistry Department, National institute of Oceanography and Fisheries, Alexandria, Egypt \\ ${ }^{2}$ Department of Chemistry, Faculty of Science, Monofiya University, Monofiya, Egypt \\ ${ }^{3}$ Department of Chemistry, Faculty of Science, Alexandria University, Alexandria, Egypt \\ Email address: \\ saharty@yahoo.com (A. El-Saharty) \\ ${ }^{*}$ Corresponding author
}

\section{To cite this article:}

Abeer El-Saharty, Shaimaa Nasser Mahmoud, Ahmed Hashem Manjood, Adel Abdel Hady Nassar, Abdel Moneum Ahmed. Effect of Apricot Stone Activated Carbon Adsorbent on the Removal of Toxic Heavy Metals Ions from Aqueous Solutions. International Journal of Ecotoxicology and Ecobiology. Vol. 3, No. 2, 2018, pp. 51-62. doi: 10.11648/j.ijee.20180302.13

Received: May 29, 2018; Accepted: June 25, 2018; Published: August 1, 2018

\begin{abstract}
In this work, activated carbon was prepared from apricot stone (ASAC) waste to remove the toxic heavy metal ions (Aluminum ions and zinc ions) from aqueous solutions. The effect of different parameters such as PHs, adsorbent dose, the initial heavy metal ions concentration and contact time were investigated. Adsorption isotherm, kinetics and thermodynamics of metal ions on ASAC were studied. Equilibrium data were fitted to the Langmuir and Freundlich isotherm models. Langmuir isotherm provided the best fit to the equilibrium data with maximum adsorption capacity. Kinetic studies were also undertaken in terms of pseudo-first-order and pseudo-second-order kinetic models for heavy metal ions on ASAC. The adsorption process follows the pseudo- second order kinetic with high coefficients correlation. The thermodynamic parameters $\Delta \mathrm{G}^{\circ}, \Delta \mathrm{H}^{\circ}$ and $\Delta \mathrm{S}^{\circ}$ determined, showed that the adsorption of heavy metal ions onto ASAC was feasible, spontaneous and endothermic. The results showed that ASAC is an efficient adsorbent for the adsorptive removal of heavy metal ions from aqueous solutions.
\end{abstract}

Keywords: Apricot Stone, Activated Carbon, Heavy Metal, Adsorption Isotherm, Kinetics, Thermodynamics

\section{Introduction}

The awareness of increasing water pollution implying studies concerning water treatment and the use of removal of heavy metals from industrial wastewater is of primary importance. natural materials that are available in large quantities or certain waste from agricultural processes may have potential to use low cost adsorbents, as they represent unused resources, widely available and are environmentally friendly [1]. Man's awareness of the hazards of heavy metals now covers a wide spectrum of metals such as lead, cadmium, chromium, copper and zinc [2]. Among the Aluminum- and zinc poisoning in humans cause severe dysfunction of the kidneys, reproductive system, liver, and brain and central nervous system [3]. Heavy doses of zinc salt $(165 \mathrm{mg})$ causes vomiting renal damage and cramps, while $\left(\mathrm{Al}^{+3}\right)$ is toxic especially for brain, sometimes maglev to Alzheimer's diseases in humans (4). To remove heavy metals effectively from metal laden wastewater, engineers and scientists have developed processes and measurements for the treatment and disposal of metal-containing wastes, namely, chemical precipitation, ion exchange, membrane separation and adsorption [5-8]. Adsorption is a surface process that occurs when a solute is selectively retained on the surface of an adsorbent forming a thin layer of the adsorbate [9]. Thus adsorption finds its use in the removal of 
dissolved substances from water with careful choice of adsorbent and adsorbate [10]. It involves selective retention of the adsorbates to the adsorption sites of the adsorbent [11]. Disposal of industrial wastes with an appreciable concentration of heavy metal ions is a persistent environmental issue [12]. The metals such as Aluminum, Cadmium, Zinc, Chromium, Nickel, Copper, Mercury and Lead are considered to be prominent in industrial waste streams whose removal requires keen attention [13-14]. The conventional methods in practice for the removal of heavy metal ions from waste waters include precipitation by chemical methods, ion exchange and Biosorption [15]. Although these methods are expensive they are also associated with several limitations such as the generation of sludge, low percentage retention of metal ions, energy consumption and low selectivity which makes the process less suitable for small scale industries. Thus, adsorption is proposed as an economical and effective method for the retention of heavy metal ions from aqueous industrial wastes. Adsorption is considered as an effective and economical method for the removal of metal ions from waste waters [1617]. Low cost adsorbents [18] such as nut wastes, peat moss [19], waste wool, silica gel [20], tree barks, activated carbon [21-22], saw dust [23], amla dust, etc. have been established as efficient adsorbents for the same purpose.

This work describes the removal of heavy metal ions such as Aluminum and Zinc from synthetic solutions by using adsorption on activated carbon was prepared from apricot stone (ASAC).

The aim of this research was to investigate the effect of $\mathrm{pH}$, contact time, initial concentration, temperature and dosage. Also determine the adsorption kinetics of activated carbon of apricot stone so as to better understand and optimize its role as adsorbent for Aluminum and Zinc ions in solution. While isotherm studies were used to model the adsorption process. Activated carbon of apricot stone is lowcost and readily available and this knowledge will be a contribution to the global fight against pollution.

\section{Material and Methods}

\subsection{Adsorbate}

The Metals solutions are Aluminum sulphate $\left(\mathrm{Al}_{2}\left(\mathrm{SO}_{4) 3}\right)\right.$ and Zinc sulphate $\left(\mathrm{ZnSO}_{4}\right)$.

The Stock solution $(1000 \mathrm{mg} / \mathrm{L})$ of $\left(\mathrm{Al}^{+3}\right)$ Or $\left(\mathrm{Zn}^{+2}\right)$ was prepared by dissolving the required amounts of $\left(\mathrm{Al}_{2}\left(\mathrm{SO}_{4}\right)_{3}\right)$ or $\left(\mathrm{ZnSO}_{4}\right)$ in deionized water. Aqueous solutions of metals were prepared in the laboratory based on metal concentration in the industrial effluent. Each metal solution was diluted with distilled water to obtain the desired initial concentration in the range $30-300 \mathrm{mg} / \mathrm{L}$, The solution that we used during our tests is characterized by a $\mathrm{pH}$ variance of 6 for $\left(\mathrm{Al}^{+3}\right)$ and 6.5 for $\left(\mathrm{Zn}^{+2}\right)$ and conductivity was $16.0 \mu \mathrm{S} / \mathrm{cm}$.

The working solutions were prepared by diluting the stock solution of metal ion.

The $\mathrm{pH}$ meter is calibrated by using Buffer solutions ( $\mathrm{pH} 3$ and 7). PH of each test solution was adjusted to the required value to $0.1 \mathrm{~N}$ hydrochloric acid or dilutes sodium hydroxide solutions.

\subsection{Adsorbent (ASAC)}

\section{Preparation of Activated Carbon}

Apricot stone used in this study as precursor was sourced locally. These were washed severally with distilled water to remove water-soluble impurities and dried to constant weight in an oven at $70^{\circ} \mathrm{C}$ for 2 days. The dried samples were ground and sieved by Apricot stone 200 Analytical Sieve Shakers and further dried in the oven. The sample was then soaked in orthophosphoric acid $\left(\mathrm{H}_{3} \mathrm{PO}_{4}\right)$ with an impregnation ratio of $1: 1(\mathrm{w} / \mathrm{w})$ for $24 \mathrm{~h}$ and dehydrated in an oven overnight at $105^{\circ} \mathrm{C}$. The resultant sample was activated in a closed muffle furnace to increase the surface area at $500^{\circ} \mathrm{C}$ for $2 \mathrm{~h}$. The activated carbon produced was cooled to room temperature and washed with $0.1 \mathrm{M} \mathrm{HCl}$ and successively with distilled water. Washing with distilled water was done repeatedly until the $\mathrm{pH}$ of the filtrate reached 6-7. The final product was dried in an oven at $105^{\circ} \mathrm{C}$ for $24 \mathrm{~h}$ and stored in vacuum desiccators until needed [24].

\subsection{Adsorption Experiments}

A definite volume of heavy metal ion stock solution with a known initial concentration was stirred with a definite amount of (ASAC) for the stipulated time at a fixed temperature in a mechanical shaker. The unabsorbed heavy metal ions which remained in solution were filtered and the amount of heavy metal ions was estimated after attainment of equilibrium. The extent of retention of the different metal ions by (ASAC) was studied by varying several parameters such as the initial concentration of adsorbate (30, 50,100,150and200ppm.), adsorbent dosages $(0.1-1.0 \mathrm{~g})$, solution temperature $\left(298^{\circ} \mathrm{C}-313 \mathrm{~K}\right), \mathrm{pH}(3-7)$ and contact time (5-120 minutes). The supernatant was analyzed for solution metals by means of atomic absorption spectrophotometer (AAS). The uptake of metal ions was calculated by the difference in their initial and final concentrations. The mass balance is expressed mathematically as:

$$
\mathrm{q}_{\mathrm{e}}=\mathrm{V}\left(\mathrm{C}_{0}-\mathrm{C}_{\mathrm{e}}\right) / \mathrm{M}
$$

where $\mathrm{q}_{\mathrm{e}}$ is the amount of metal ion adsorbed per unit mass of adsorbent ( $\mathrm{mg} / \mathrm{g}$ adsorbent), $\mathrm{V}$ is the volume of the metal solution ( $\mathrm{L}), \mathrm{C}_{0}$ is the initial concentration of metal ion in aqueous phase $(\mathrm{mg} / \mathrm{L}), \mathrm{C}_{\mathrm{e}}$ is the final concentration of metal ion in aqueous phase $(\mathrm{mg} / \mathrm{L})$ and $\mathrm{M}$ is the mass of adsorbent used (g). The percentage adsorption was calculated as follows:

$$
\text { Adsorption }(\%)=\left(\mathrm{C}_{0}-\mathrm{C}_{\mathrm{e}}\right) * 100 / \mathrm{C}_{0}
$$

Freundlich and Langmuir isotherms were also studied for varying concentrations of the different metal ions at constant temperature. 


\section{Results and Discussion}

\subsection{Characterization of Activated Carbon}

\subsubsection{Fourier Transform Infrared (FTIR) Analysis}

The FTIR spectrum analysis is important to identify the characteristic functional groups of the biosorbent, which are responsible for adsorption of heavy metal ions, the data in Figure 1. Shows abroad band ranging from $3409-3350 / \mathrm{cm}$ represent O-H stretching, two bands at 2807 \& 2909/cm correspond to stretching of the $\mathrm{C}-\mathrm{H}$ bonds of the methyl and methylene groups present in the structure. Band around $2361.41 / \mathrm{cm}$ is characteristic of the $\mathrm{C}=\mathrm{C}$ stretching vibration of alkyne groups [25]. Peak occurring at $1529.27 / \mathrm{cm}$ is characteristic of $\mathrm{C}=\mathrm{C}$ stretching vibration of aromatic ring [26]. The peak observed at $1730.8 / \mathrm{cm}$ is due to $\mathrm{C}=\mathrm{O}$ stretching in the ketone, aldehydes, lactones or carboxyl groups. From the FTIR analysis, it is clear that some surface functional groups are present on the ASAC that might be involved in the heavy metal ions adsorption process.

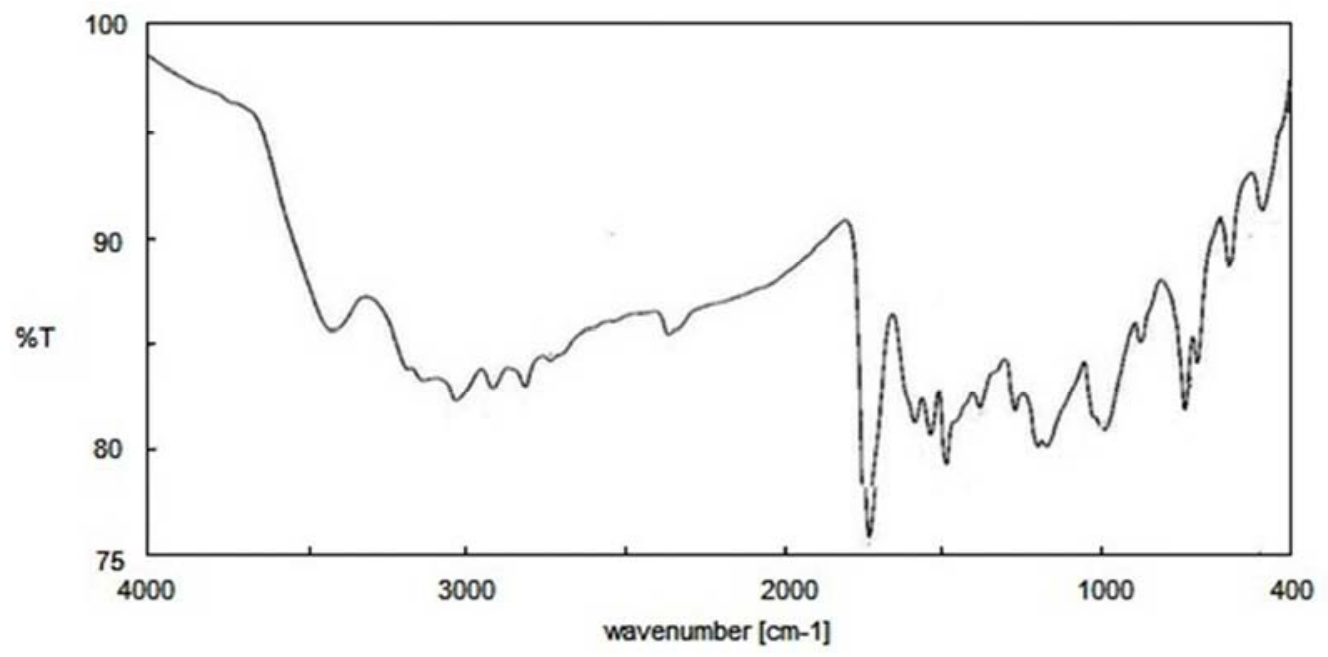

Figure 1. Fourier transform infrared (FTIR) spectrum of ASAC.

\subsubsection{Scanning Electron Microscopy}

The microstructure of the ASAC was observed by SEM at 200x magnification and is shown in Figure 2. This figure shows that the adsorbent had an irregular shape and porous surface, indicating relatively high surface areas. The size distribution of micro pores of activated carbon had no definite morphology. This observation is supported by the BET surface area of the ASAC. The values of BET surface areas and average pore diameter obtained for ASAC were $566 \mathrm{~m}^{2} / \mathrm{g}$ and $0.32 \mathrm{~nm}$, respectively. According to the IUPAC recommendation, total porosity can be classified into three groups which were macrospores $(\mathrm{d}>50 \mathrm{~nm})$, mesopores $(2<\mathrm{d}<50 \mathrm{~nm})$ and micro pores $(\mathrm{d}<2 \mathrm{~nm})$. Based on the average pore diameter value, ASAC falls into the category of micro pores.

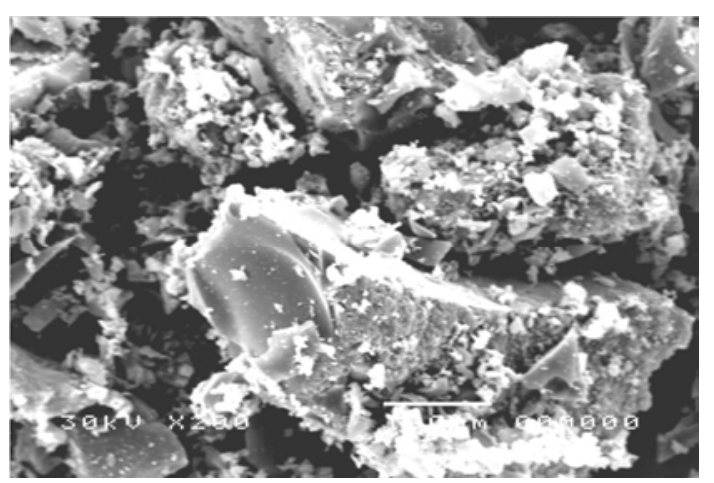

Figure 2. Scanning electron microscopy (SEM) of ASAC.

\subsection{Effect of $\mathrm{pH}$}

$\mathrm{pH}$ in solution has been identified as the most important variable governing metal adsorption on bio sorbents. This is partly due to the fact that hydrogen ions themselves are strongly competing adsorbates. The solution $\mathrm{pH}$ influences the speciation of metal ions and the ionization of surface functional groups. The effect of $\mathrm{pH}$ for Aluminum and zinc removal in a ligand-free system is shown in Figures: (3) and (4); the Effect of $\mathrm{pH}$ on process of adsorption movement on (ASAC) was at a range of $(3-7)$ as it is in (Figures). The optimal $\mathrm{pH}$ ranges for Aluminum and zinc were $\mathrm{pH} 6.0$ and 6.5 , respectively. The maximum removal was $92.86 \%$ for Aluminum, and $93.88 \%$ for zinc. These experimental results indicate that the binding of Aluminum and zinc is $\mathrm{pH}$ dependent; this depends on the ion state and nature of material.

The increase in metal removal with $\mathrm{pH}$ is due to a decline in competition between proton and metal species for surface sites; thereby decreasing in positive surface charge and resulting in a lower Columbic repulsion of the adsorbed metal.

In low $\mathrm{pH}$ value, binding sites are generally protonated or positively charged (by the hydronium ions). Thus, repulsion occurs between the metal cation and the adsorbent at a higher $\mathrm{pH}$ value; binding sites start deprotonating, and makes different functional groups available for metal binding. In general, cation binding increases as $\mathrm{pH}$ increases [27]. 

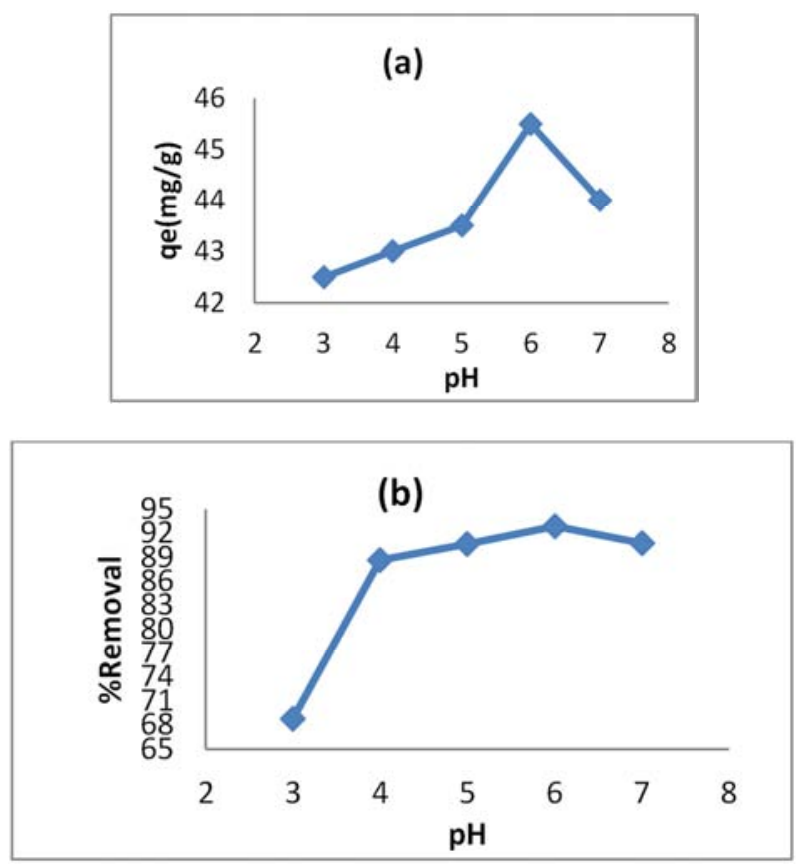

Figures 3. Effect of $\mathrm{pH}$ for $[(\mathrm{a})$ the adsorbed quantity qe $(\mathrm{mg} / \mathrm{g}) \&$ (b)\%Removal], of $\left(\mathrm{Al}^{+3}\right)$ on $(\mathrm{ASAC})$ (The initial concentration $=100 \mathrm{mg} / \mathrm{l}$, adsorbent doses $=0.5 \mathrm{~g} / 250 \mathrm{ml}$, stirring speed $=300 \mathrm{rpm} T=298 \mathrm{~K}$ and at time $=120 \mathrm{~min}$ ).
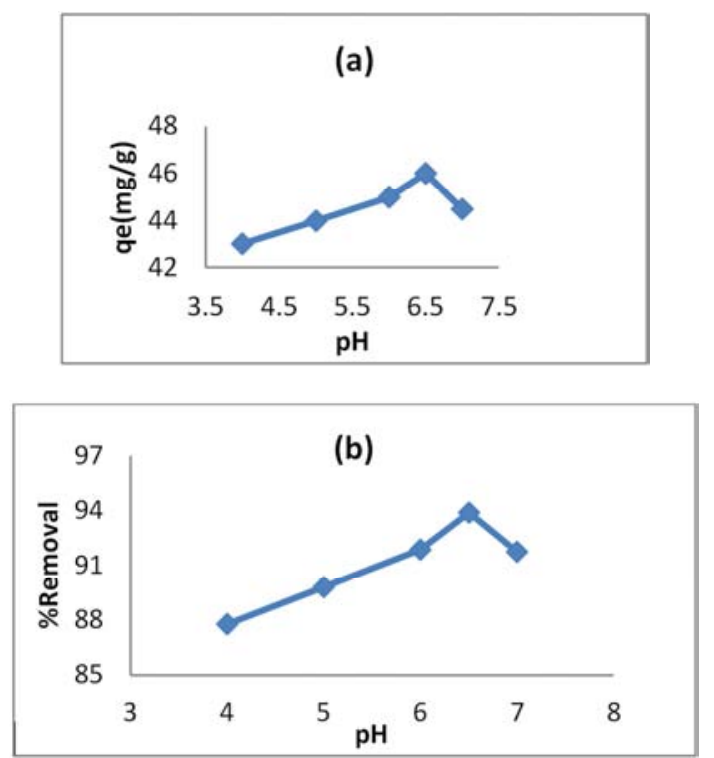

Figures 4. Effect of $\mathrm{pH}$ for $[(\mathrm{a})$ the adsorbed quantity qe $(\mathrm{mg} / \mathrm{g})$ \& (b)\%Removal], of $\left(\mathrm{Zn}^{+2}\right)$ on $(A S A C)$ (The initial concentration $=100 \mathrm{mg} / \mathrm{l}$, adsorbent doses $=0.5 \mathrm{~g} / 250 \mathrm{ml}$, stirring speed $=300 \mathrm{rpm} T=298 \mathrm{~K}$ and at time $=120 \mathrm{~min}$.

\subsection{Effect of Contact Time}

Equilibrium time is important operational parameter for an economical wastewater treatment process. The time required to achieve the adsorption equilibrium on the adsorption capacity of $\left(\mathrm{Al}^{+3}\right)$ and $\left(\mathrm{Zn}^{+2}\right)$ is described in Figure 5. Obviously, (ASAC) showed a good performance in adsorption during the first $30 \mathrm{~min}$ and there is no significant change from 30 to $120 \mathrm{~min}$. Two - stage behavior is observed. It is observed from the results that the uptake of $\left(\mathrm{Al}^{+3}\right)$ and $\left(\mathrm{Zn}^{+2}\right)$ is initially quite high and slows down with the lapse of time leading gradually to an equilibrium condition. It also shows that a major fraction of $\left(\mathrm{Al}^{+3}\right)$ and $\left(\mathrm{Zn}^{+2}\right)$ is adsorbent onto (ASAC) during the first 30 min, while only a very small part of the additional adsorption occurs during the following contact time. This clearly suggests that the adsorption of metal cations on the surface of the (ASAC) could take place in a single step and without any complexity. Thus, it is possible that during the initial stage of the process, the surface coverage is low and adsorptive ions occupy active surface sites rapidly in a random manner. As a result, the rate of uptake is higher. As time lapses the surface coverage increases, the rate of uptake becomes slower in the latter stages and ultimately an almost plateau region is attained when the surface becomes saturated $(28,29)$.
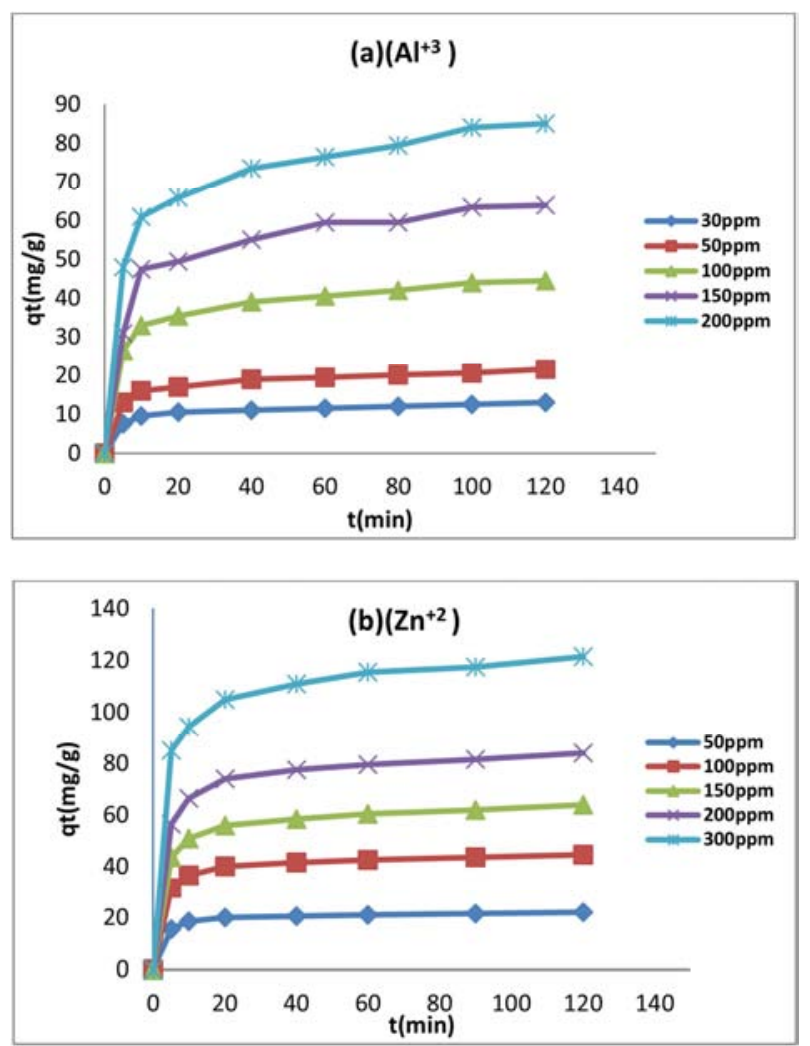

Figure 5. Effect of contact time on the adsorption quantity of $\left[(a)\left[\left(A l^{+3}\right)\right.\right.$ at $\mathrm{pH}=6$, initial concentration $=30 \mathrm{to} 200 \mathrm{mg} / \mathrm{l}$ and (b) $\left(\mathrm{Zn}^{+2}\right) \mathrm{pH}=6.5$, initial concentration $=50 t 0300 \mathrm{mg} / \mathrm{l}]$, (ASAC) dose $=0.5 \mathrm{~g} / 250 \mathrm{ml}, 300 \mathrm{rpm}$, contact time $=120 \mathrm{~min}$ and temperature $=298 \mathrm{~K}$ ).

\subsection{Effect of Amount Adsorbed}

Since an optimum adsorbent dose is essentially required to maximize the interactions between metal ions and adsorption sites of adsorbent in the solution, the effect of adsorbent dose of $\left(\mathrm{Al}^{+3}\right)$ and $\left(\mathrm{Zn}^{+2}\right)$ ions adsorption was investigated. Figures 6, 7 showed that the increase in the dose of the adsorbents (activated carbon of apricot stone concentrations range from 0.1-1.0 g/250 $\mathrm{mL})$ increases $\left(\mathrm{Al}^{+3}\right)$ and $\left(\mathrm{Zn}^{+2}\right)$ uptake. Namely, the percentage removal increases as the adsorbent doses increases these observations suggest that the increase in (ASAC) concentration 
leads to increase in the adsorbent surface area and the availability of more adsorption sites for metal ions adsorption. Therefore, the maximum removal efficiency of metal is $94.85 \%$ of $\left(\mathrm{Al}^{+3}\right)$ and $95.92 \%$ of $\left(\mathrm{Zn}^{+2}\right)$ at $1.0 \mathrm{~g} / \mathrm{mL}$ dose of (ASAC). Furthermore, as shown in Figures 6, 7, the amount of metal ion adsorbed per unit weight of adsorbents $\left(\mathrm{q}_{\mathrm{e}}\right)$ increase with the increase in (ASAC) doses. The initial increment in adsorption capacity with an increase in adsorbent dosage was expected, since a number of adsorbent particles increases and thus more surface areas were available for metals attachment same trend was reported (30), (31). It is plausible to suggest that with a higher dosage of adsorbent there would be greater availability of the exchangeable site of metal ions. An increase in $\%$ removal of $\left(\mathrm{Al}^{+3}\right)$ and $\left(\mathrm{Zn}^{+2}\right)$ ions has been observed on increasing the dosage of the adsorbent. The number of sites available for adsorption increases with increase in surface area of the adsorbent. This facilitates an increase in the retention percentage of the metal ions with an increase in the dosage of the adsorbent.
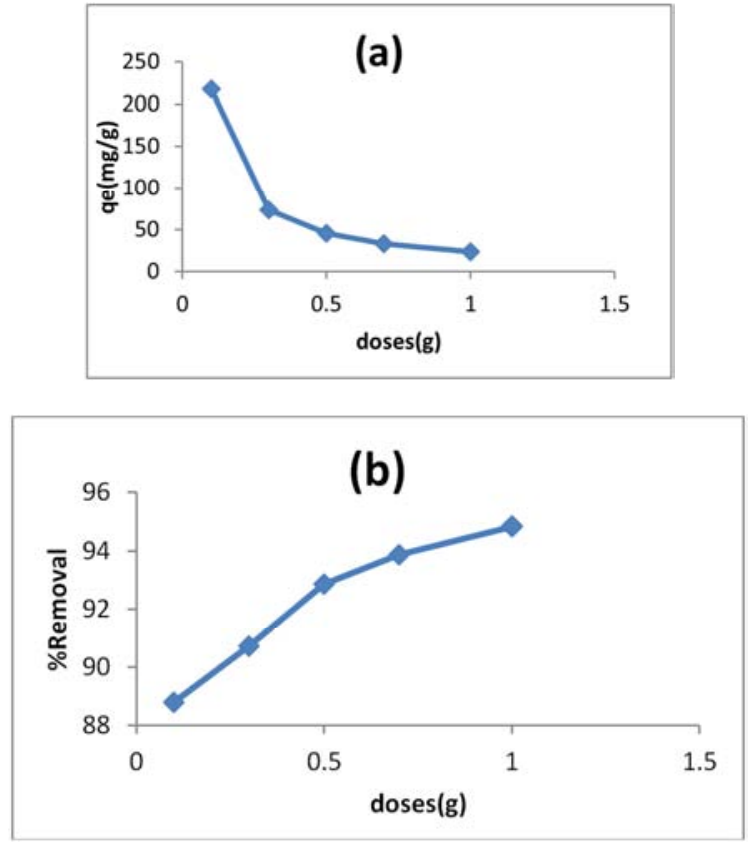

Figures 6. The Effect of $(A S A C)$ doses ( $g$ ) on [(a) the adsorbed quantity qe $(\mathrm{mg} / \mathrm{g}) \&(\mathrm{~b}) \%$ Removal], of $\left(\mathrm{Al}^{+3}\right)$ on $(\mathrm{ASAC})$ at initial concentration $=100$ $\mathrm{mg} / \mathrm{l}, \mathrm{PH}=6$, solution volume $=250 \mathrm{ml}, T=298 \mathrm{~K}, 300 \mathrm{rpm}$ and at time $=$ $120 \mathrm{~min}$.

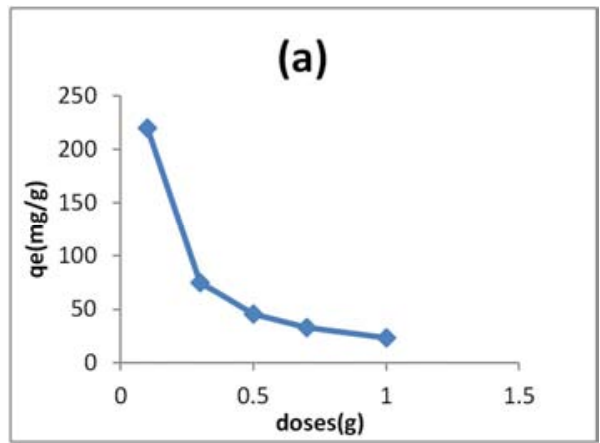

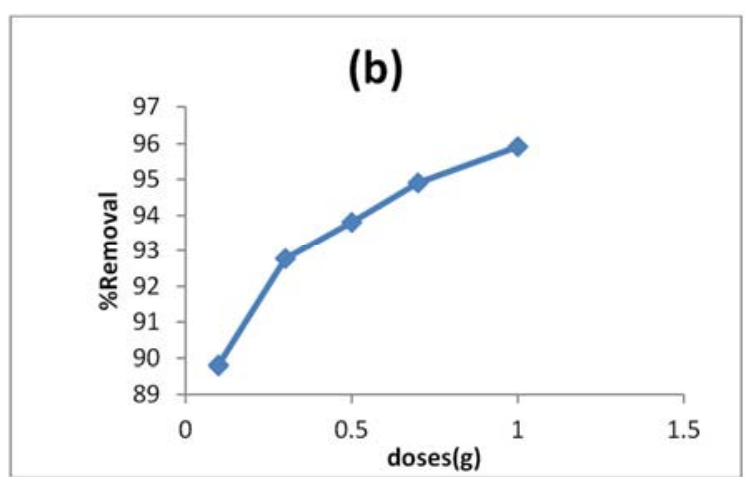

Figures 7. The Effect of (ASAC) doses ( $\mathrm{g}$ ) on [ (a) the adsorbed quantity qe ( $\mathrm{mg} / \mathrm{g})$ $\&(b) \%$ Removall, of $\left(\mathrm{Zn}^{+2}\right)$ on $(\mathrm{ASAC})$ at initial concentration $=100 \mathrm{mg} / \mathrm{l}$, $P H=6.5$, solution volume $=250 \mathrm{ml}, T=298 \mathrm{~K}, 300 \mathrm{rpm}$ and at time $=120 \mathrm{~min}$.

\subsection{Effect of Initial Heavy Metal Ion Concentration}

Figure 6 showed the effect of varying the initial concentration of $\left(\mathrm{Al}^{+3}\right)$ or $\left(\mathrm{Zn}^{+2}\right)$ ions from 30 to $200 \mathrm{mg} / \mathrm{L}$ for $\left(\mathrm{Al}^{+3}\right)$ and from 50 to $300 \mathrm{mg} / \mathrm{L}$ for $\left(\mathrm{Zn}^{+2}\right)$ on the adsorption under the optimized condition at $\mathrm{pH} 6,6.5$ for $\left(\mathrm{Al}^{+3}\right)$ and $\left(\mathrm{Zn}^{+2}\right), 298 \mathrm{~K}$ and $0.5 \mathrm{~g}$ of (ASAC). It can be seen from the figure 8 that, with increasing $\left(\mathrm{Al}{ }^{+3}\right)$ and $\left(\mathrm{Zn}^{+2}\right)$ initial concentration, there is a decrease in $\%$ removal of $\left(\mathrm{Al}^{+3}\right)$ and $\left(\mathrm{Zn}^{+2}\right)$ for adsorbent. This can be explained with the fact that the adsorbent had a limited number of active sites, which would have become saturated above certain concentration. Similar observations have also been reported from other researches (32), (33). In another word, at higher concentration of metal ions the \% removal decrease this may be due to the lake of available active sites required for the high initial concentration of $\left(\mathrm{Al}^{+3}\right)$ and $\left(\mathrm{Zn}^{+2}\right)$, This may be due to the fact that at a fixed adsorbent dose, The number of active adsorption sides to accommodate the adsorbate ions remains unchanged while with higher adsorbate concentrations.
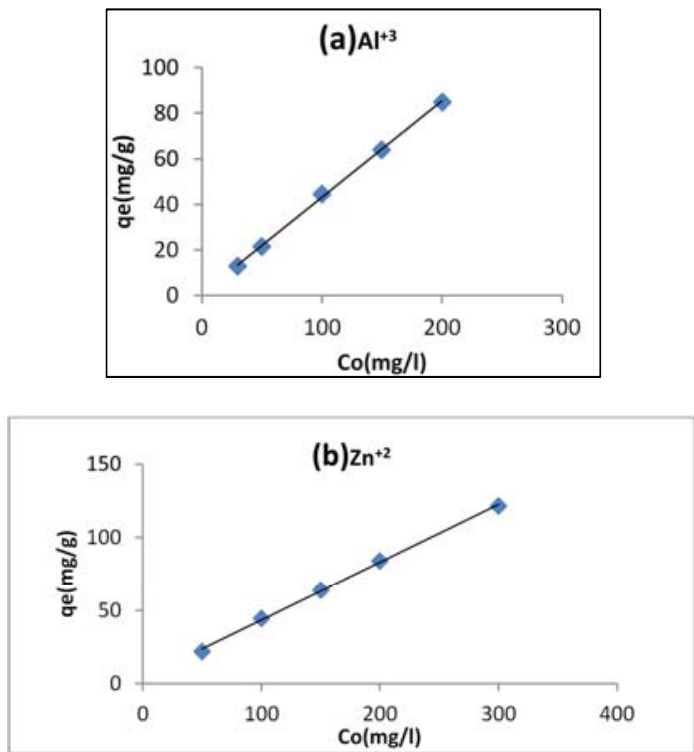

Figures 8. The Effect of initial concentration for the adsorbed quantity qe $(\mathrm{mg} / \mathrm{g})$ of $\left[(\mathrm{a})\left(\mathrm{Al}^{+3}\right)\right.$ at $\mathrm{PH}=6 \mathrm{\& b}\left(\mathrm{Zn}^{+2}\right)$ at $\left.\mathrm{PH}=6.5\right]$ on $(\mathrm{ASAC})$ (adsorbent doses $=0.5 \mathrm{~g} / 250 \mathrm{ml}$, stirring speed $=300 \mathrm{rpm} T=298 \mathrm{~K}$ and at time $=$ 120min). 


\subsection{Effect of Temperature}

Figure 9: Represents the change in extent of adsorption with respect to temperature. A linear increase in $\%$ adsorption is observed which indicates an endothermic process. The retention of metal ions increases with increasing temperature, which may be attributed to the activation of (ASAC) at increased temperatures [19]. This suggests the monolayer coverage of the surface of (ASAC) by the metal ions which may be followed by other extra layers of molecules which may be physically adsorbed [34].
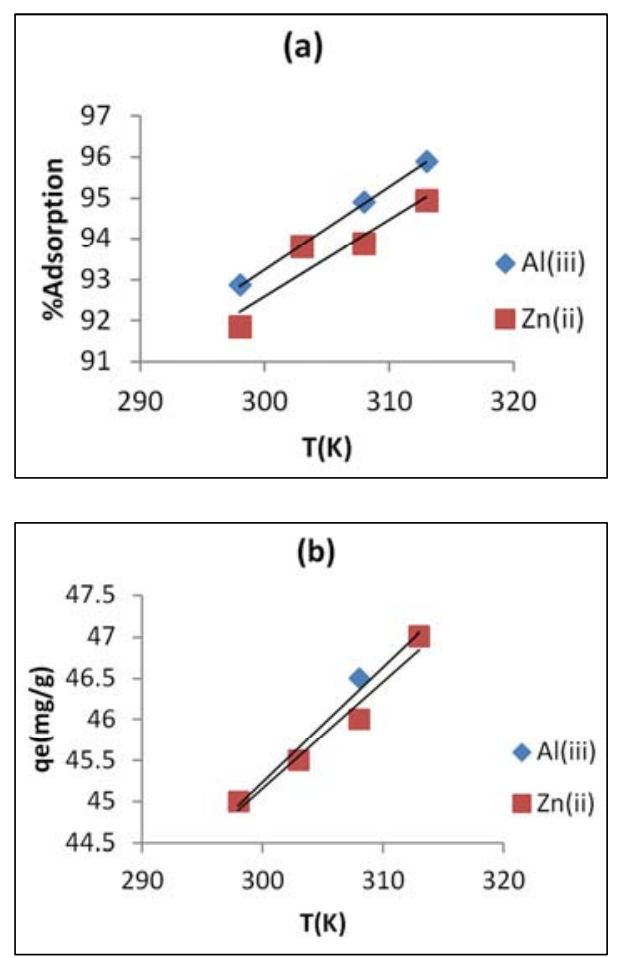

Figures 9. The Effect of Temp ( $k$ ) on (a) \% Removal and (b) $q_{e}(\mathrm{mg} / \mathrm{g}$ ) of (Al $\left.{ }^{+3}\right)$ and $\left(\mathrm{Zn}^{+2}\right)$ on $(\mathrm{ASAC})$ at $\left(\mathrm{PH}=6\right.$ for $\left(\mathrm{Al}^{+3}\right)$ and $\mathrm{PH}=6.5$ for $\left.\left(\mathrm{Zn}^{+2}\right)\right)$, initial concentration $=100 \mathrm{mg} / \mathrm{l},(A S A C)$ dose $=0.5 \mathrm{~g} / 250 \mathrm{ml}, 300 \mathrm{rpm}$ and at time $=$ $120 \mathrm{~min}$.

Effects of temperature on the adsorption of Aluminum and zinc ions by (ASAC) were investigated at 298-313 K and an initial metal ion concentration of $100 \mathrm{mg} / \mathrm{L}$ and $300 \mathrm{rpm}$ for Aluminum and zinc, optimum $\mathrm{pH}$ values of 6 for Aluminum and 6.5 for zinc and $0.5 \mathrm{~g} / 250 \mathrm{~mL}$ of (ASAC). As shown in Figure 10, the adsorption capacities for (ASAC) increased with the increase in temperature, revealing both the adsorption processes were endothermic. The increase in adsorption with temperature may be attributed to either increase the number of active surface sites available for adsorption on the adsorbent or the desolvation of the adsorbing species and the decrease in the thickness of the boundary layer surrounding the adsorbent with temperature, so that the mass transfer resistance of the adsorbate in the boundary layer decreases [35].
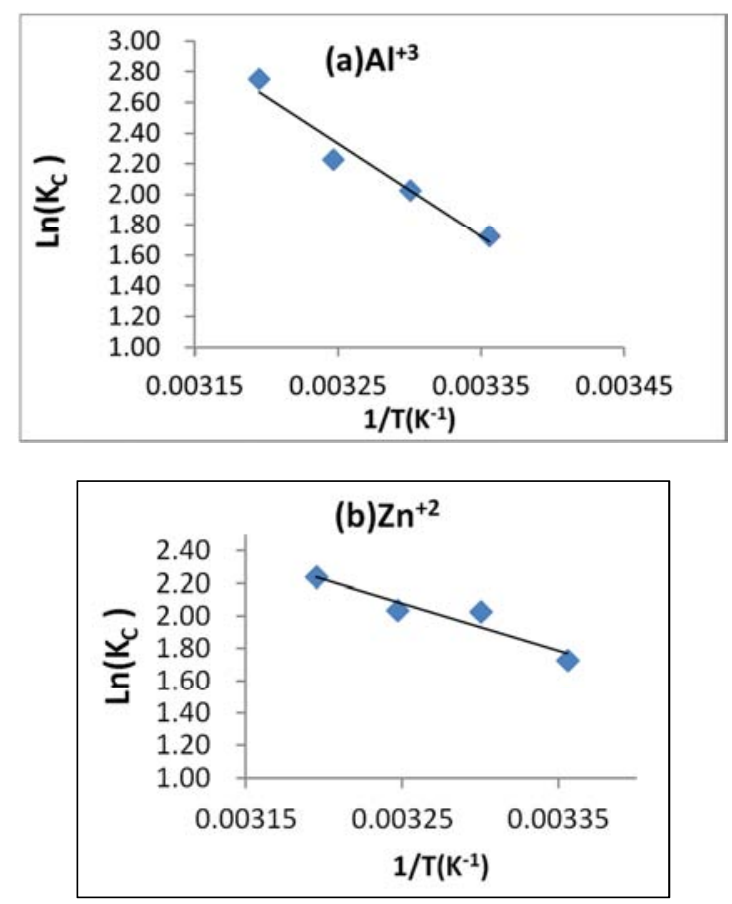

Figures 10. Relation between In $\left(K_{e}\right)$ and reciprocal of temperature $(1 / T)$, at constant initial concentration of $100 \mathrm{mg} / \mathrm{l}, 0.5 \mathrm{~g} / 250 \mathrm{ml}$ of (ASAC) and300rpm for (a) Aluminum ions and (b) zinc ions.

Since diffusion is an endothermic process, greater adsorption will be observed at higher temperature. Thus, the diffusion rate of ions in the external mass transport process increases with temperature. Another possible explanation was that the metal ions were well hydrated. They have to lose part of the hydration sheath in order to be adsorbed. This dehydration process of metal ions needed energy and superseded the exothermicity of the ion adsorption on the surface (36). Temperature is an important parameter in the adsorption process and to determine the spontaneity of the process in engineering practice, thermodynamic parameters such as enthalpy change $\left(\Delta \mathrm{H}^{0}\right)$, entropy change $\left(\Delta S^{0}\right)$ and free energy change $\left(\Delta G^{0}\right)$ are crucial and must be taken into consideration. These thermodynamic parameters are obtained from adsorption experiments at various temperatures (298, 303, 308 and 313K) and estimated (Table-1) using the following equations:

$$
\begin{gathered}
\mathrm{K}_{\mathrm{c}}=-\mathrm{q}_{\mathrm{e}} / \mathrm{C}_{\mathrm{e}} \\
\Delta \mathrm{G}^{0}=-\mathrm{RT} \mathrm{In} \mathrm{K}_{\mathrm{C}} \\
\operatorname{LnK}_{\mathrm{c}}=\left(\Delta \mathrm{S}^{0} / \mathrm{R}\right)-\left(\Delta \mathrm{H}^{0} / \mathrm{RT}\right)
\end{gathered}
$$

Where $K_{C}$ is the equilibrium constant, $\mathrm{q}_{\mathrm{e}}\left(\mathrm{mg} \mathrm{I}^{-1}\right)$ is the concentration of $\left(\mathrm{Al}^{+3}\right)$ and $\left(\mathrm{Zn}^{+2}\right)$ adsorbed on solid at equilibrium, $\mathrm{C}_{\mathrm{e}}\left(\mathrm{mg} \mathrm{L}^{-1}\right)$ is the equilibrium concentration of $\left(\mathrm{Al}{ }^{+3}\right)$ and $\left(\mathrm{Zn}^{+2}\right)$ in the solution $\mathrm{R}\left(8.314 \mathrm{JK}^{-1} \mathrm{~mol}^{-1}\right)$ is the gas constant and $\mathrm{T}(\mathrm{K})$ is temperature. The values of $\Delta \mathrm{H}^{0}$ and $\Delta \mathrm{S}{ }^{0}$ are obtained from the slope and intercept of the van't Hoff plot of in $\mathrm{K}$ versus $1 / \mathrm{T}$ as indicated in the inset of Figure 10 . From the slope $\left(-\Delta \mathrm{H}^{0} / \mathrm{R}\right)$, the changes of enthalpy $\left(\Delta \mathrm{H}^{0}\right)$ at $298-313 \mathrm{~K}$ could be determined to be $50.699 \mathrm{~kJ} / \mathrm{mol}$ for Aluminum and 24.10forzincand from the intercept 
$\left(\Delta S^{0} / \mathrm{R}\right)$, while the changes of entropy is $182.9(\mathrm{~J} / \mathrm{molK})$ for Aluminum and $95.6(\mathrm{~J} / \mathrm{molK})$ for zinc. The positive value of $\Delta \mathrm{H}^{0}$ confirmed the endothermic nature of adsorption which was also supported by the increase in value of $\left(\mathrm{Al}^{+3}\right)$ and $\left(\mathrm{Zn}^{+2}\right)$ uptake with the rise in temperature. The positive value of $\Delta \mathrm{S}^{\circ}$ suggested the increasing randomness at the solid/liquid interface during the adsorption of $\left(\mathrm{Al}^{+3}\right)$ and $\left(\mathrm{Zn}^{+2}\right)$ ions on (ASAC).

Table 1. Thermodynamic parameters foradsorption process.

\begin{tabular}{llll}
\hline Temp (k) & $\mathbf{G}^{\mathbf{0}}(\mathbf{K J} / \mathbf{m o l}) \Delta$ & $\mathbf{H}^{\mathbf{0}}(\mathbf{k j} / \mathbf{m o l}) \Delta$ & $\mathbf{S}^{\mathbf{0}}(\mathbf{j} / \mathbf{m o l ~ k}) \Delta$ \\
\hline Aluminum $\left(\mathrm{Al}^{+3}\right)$ & & \\
298 & -4.279 & & \\
303 & -5.103 & 50.6988 & 182.9 \\
308 & -5.710 & & \\
313 & -7.160 & & \\
Zinc $\left(\mathrm{Zn}^{+2}\right)$ & & & \\
298 & -4.279 & 24.10 & 95.6 \\
303 & -5.104 & & \\
308 & -5.216 & & \\
313 & -5.831 & & \\
\hline
\end{tabular}

The negative values for $\Delta \mathrm{G}^{\circ}$ indicate that adsorption is a feasible and spontaneous process, where no energy input from outside of the system is required. The increase of negativity $\mathrm{AG}^{0}$ values with temperature implies that the adsorption reaction is more spontaneous and more favorable at high temperature.

\subsection{Effect of Speed of Rotation}

Experimental results for the effect of speed of rotation $(100,200,300,400,500 \mathrm{rpm})$ are present in figures 11: the removal of $\left(\mathrm{Al}{ }^{+3}\right)$ and $\left(\mathrm{Zn}^{+2}\right)$ using activated carbon of apricot stone reaches $95.92 \%$ for $\left(\mathrm{Al}^{+3}\right)$ at $500 \mathrm{rpm}$ and $95.88 \%$ for $\left(\mathrm{Zn}^{+2}\right)$ at $500 \mathrm{rpm}$.
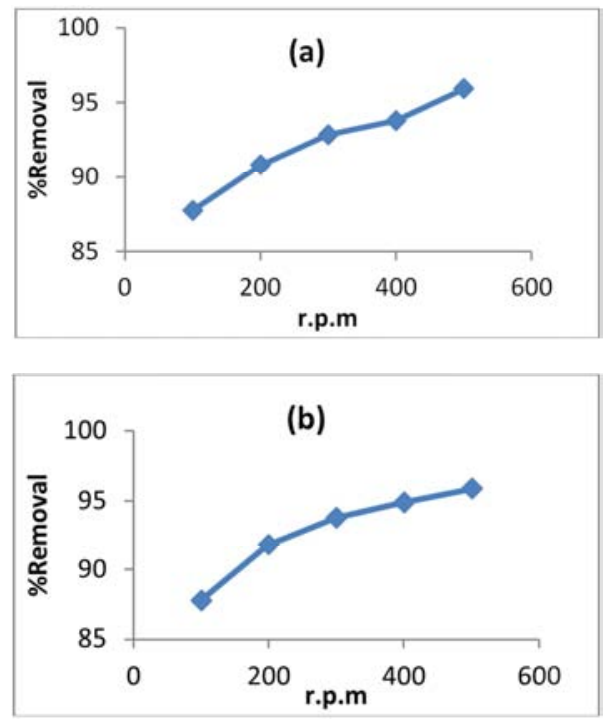

Figures 11. The Effect of rotation speed (rpm) for $\left[(\mathrm{a})\left(\mathrm{Al}{ }^{+3}\right) \&(b)\left(\mathrm{Zn}^{+2}\right)\right]$ on $\%$ Removal, on (ASAC) (at initial concentration $=100 \mathrm{mg} / \mathrm{l}, \mathrm{PH}=6$ for $\left(\mathrm{Al}^{+3}\right), 6.5$ for $\left(\mathrm{Zn}^{+2}\right)$, adsorbent doses $=0.5 \mathrm{~g} / 250 \mathrm{ml}, \mathrm{T}=298 \mathrm{~K}$ and at time $\left.=120 \mathrm{~min}\right)$.

It is obvious that speed of rotation helps metal removal from aqueous solutions. This is because metal ions, through their transportation to solid phase, meet resistance at the liquid phase, through the boundary layer. Rotation during experiments has led to a decrease of the boundary layer and a decrease to the resistance of transportation of metal ions. This increases the transfer rate of the ions.

\subsection{Effect of Volume}

It is clear that $\left(\mathrm{q}_{\mathrm{e}}\right)$ increase with increasing solution volume from 50 to $300 \mathrm{ml}$ and this can explained on the basis that there is plenty of active sites on the surface of the adsorbent that can absorb more $\left(\mathrm{Al}{ }^{+3}\right)$ and $\left(\mathrm{Zn}^{+2}\right)$ by increasing its solution volume. Mathematically, $\left(\mathrm{q}_{\mathrm{e}}\right)$ is directly proportional with the adsorbate volume.
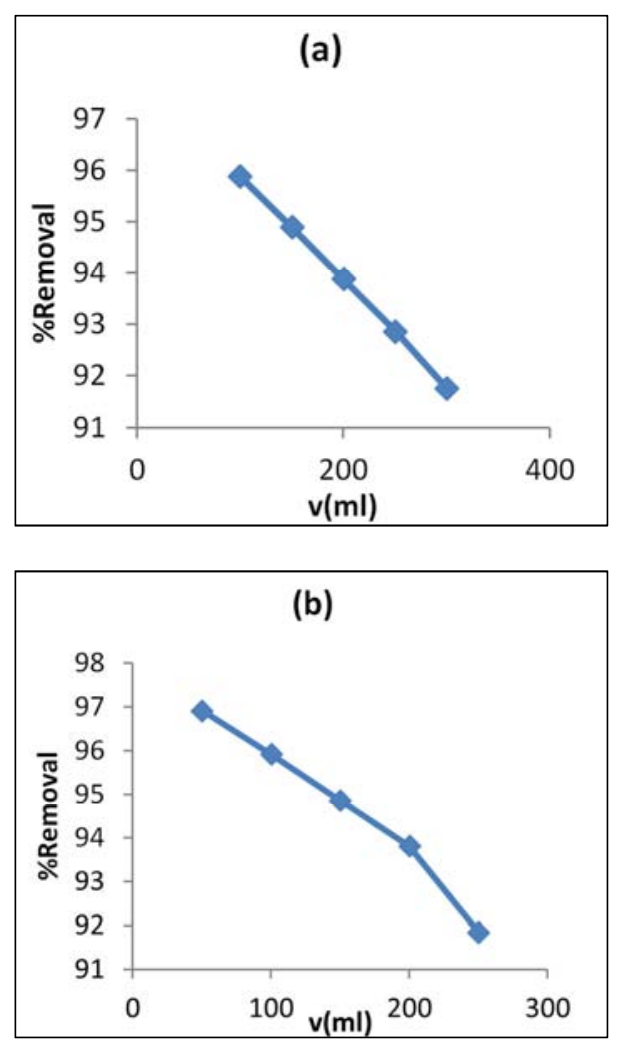

Figures 12. The Effect of volume (ml) for $\left[(a)\left(A l^{+3}\right) \&(b)\left(\mathrm{Zn}^{+2}\right)\right]$ on $\%$ Removal, on (ASAC) (at initial concentration $=100 \mathrm{mg} / \mathrm{l}, \mathrm{PH}=6$ for $\left(\mathrm{Al}^{+3}\right)$, 6.5 for $\left(\mathrm{Zn}^{+2}\right)$, adsorbent doses $=0.5 \mathrm{~g}, 300 \mathrm{rpm}, \mathrm{T}=298 \mathrm{~K}$ and at time $=$ $120 \mathrm{~min})$.

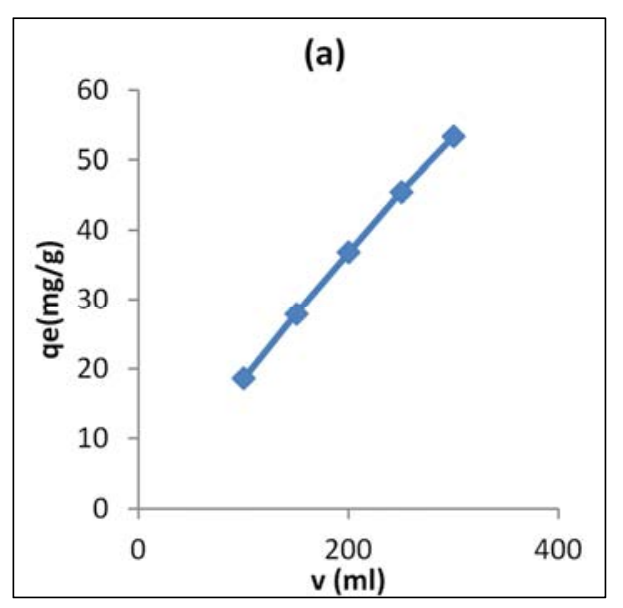




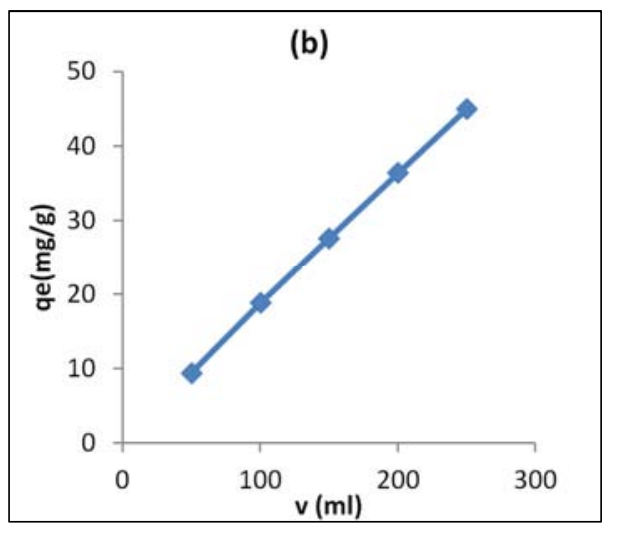

Figures 13. The Effect of volume (ml) for $\left[(a)\left(A l^{+3}\right) \&(b)\left(\mathrm{Zn}^{+2}\right)\right]$ on $q_{e}$ $(\mathrm{mg} / \mathrm{g})$, on $(A S A C)$ (at initial concentration $=100 \mathrm{mg} / \mathrm{l}, \mathrm{PH}=6$ for $\left(\mathrm{Al}^{+3}\right), 6.5$ for $\left(\mathrm{Zn}^{+2}\right)$, adsorbent doses $=0.5 \mathrm{~g}, 300 \mathrm{rpm}, \mathrm{T}=298 \mathrm{~K}$ and at time $\left.=120 \mathrm{~min}\right)$.

\subsection{Kinetic Studies}
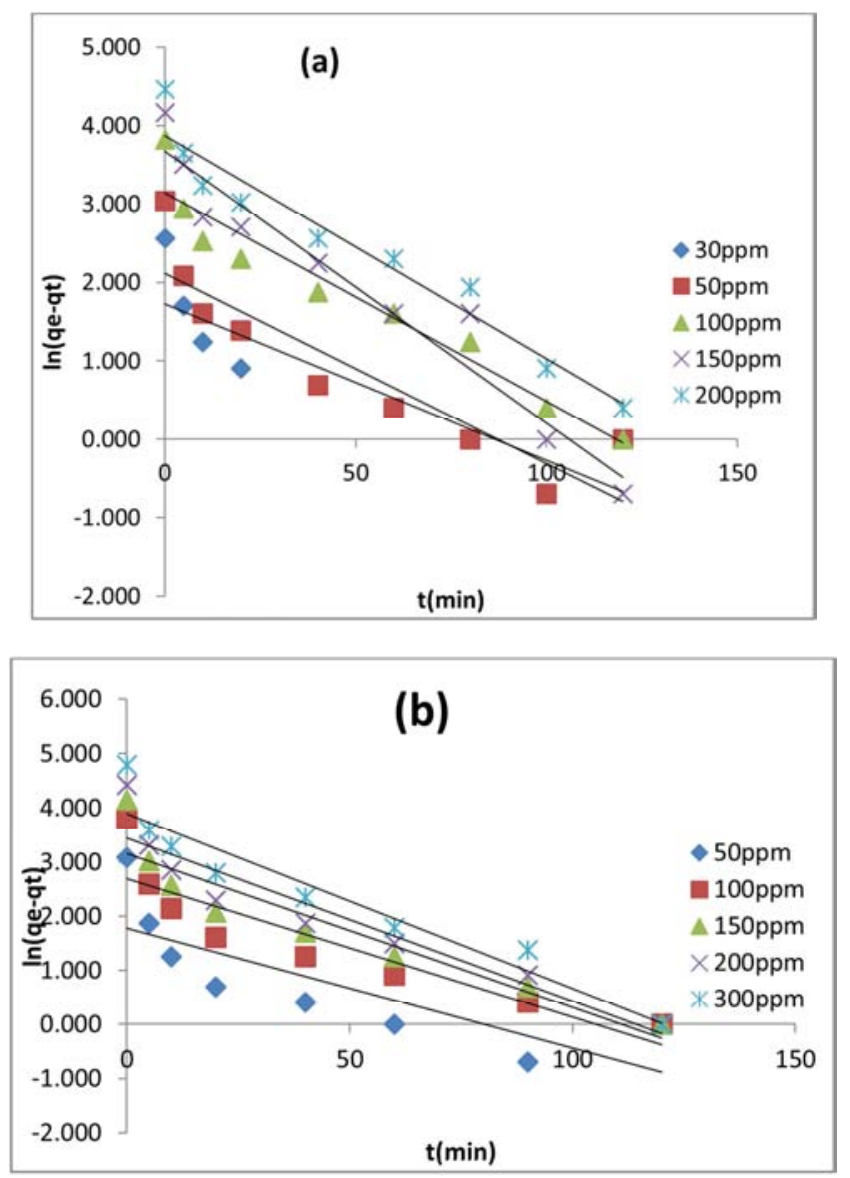

Figures 14. Pseudo-first order kinetic for adsorption of (a) Aluminum and (b) zinc on to activated carbon of apricot stone at different initial concentrations, $0.5 \mathrm{~g} / 250 \mathrm{ml}$ (ASAC), 300rpm and $298 \mathrm{~K}$.
The kinetics of adsorption describes the rate of metal ion uptake on activated carbon of apricot stone and this rate controls the equilibrium time. The kinetics of adsorbate uptake is required for selecting optimum operating condition for the full scale adsorption process (37). The kinetic parameter, which is helpful for the prediction of adsorption rate, gives important information for designing and modeling the processes. The kinetics of the adsorption data were analyzed using different kinetic models such as pseudo-first order (Figure 14) and pseudo-second order (Figure 15) models.

Pseudo first order model (Lagergren equation) (38):

$$
\operatorname{In}\left(\mathrm{q}_{\mathrm{e}}-\mathrm{q}_{\mathrm{t}}\right)=\ln \left(\mathrm{q}_{\mathrm{e}}-\mathrm{k}_{1} \mathrm{t}\right)
$$

Pseudo second order (37):

$$
\mathrm{t} / \mathrm{q}_{\mathrm{t}}=\mathrm{t} / \mathrm{q}_{\mathrm{e}}+\mathrm{k}_{2} \mathrm{q}_{\mathrm{e}}^{2}
$$

The pseudo second order reaction rate model was found to be the best to describe the kinetic data. The applicability of this model showed that sorption process is complex and involve more than one mechanism. The rate constant $\mathrm{k}$, the correlation coefficient $\mathrm{R}^{2}$ at equilibrium state was calculated in Table-2.

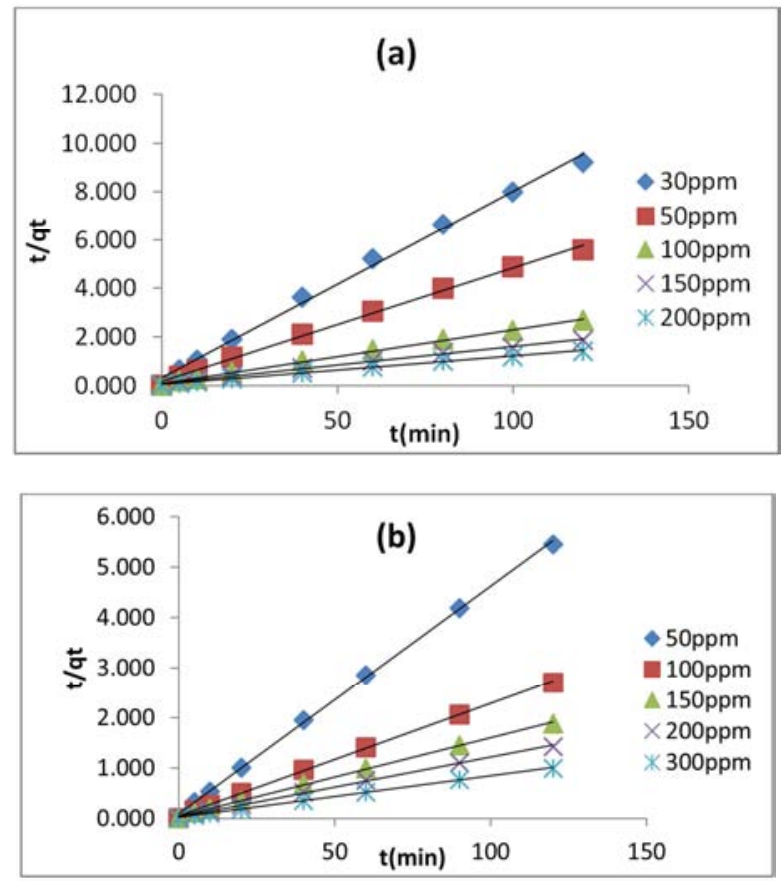

Figures 15. Pseudo Second order kinetic for adsorption of (a) Aluminum and (b) zinc on to activated carbon of apricot stone at different initial concentrations, $0.5 \mathrm{~g} / 250 \mathrm{ml}$ (ASAC), 300rpm and $298 \mathrm{~K}$.

\begin{tabular}{|c|c|c|c|c|c|c|c|}
\hline \multirow{6}{*}{ (a) Aluminum $\left(\mathrm{Al}^{+3}\right)$} & \multirow{3}{*}{ Kinetic model } & \multirow{2}{*}{ parameters } & \multicolumn{5}{|c|}{ Concentration $(\mathrm{mg} / \mathrm{l})$} \\
\hline & & & $30 \mathrm{mg} / 1$ & $50 \mathrm{mg} / 1$ & $100 \mathrm{mg} / \mathrm{l}$ & $150 \mathrm{mg} / \mathrm{l}$ & $200 \mathrm{mg} / 1$ \\
\hline & & $\mathrm{q}_{\mathrm{e}}, \exp (\mathrm{mg} / \mathrm{g})$ & 13.00 & 21.50 & 44.50 & 64.00 & 85.00 \\
\hline & \multirow{3}{*}{ Pseudo first -order } & $(\mathrm{mg} / \mathrm{g}) \mathrm{q}_{\mathrm{e}}, \mathrm{cal}$ & 5.601 & 8.298 & 23.058 & 39.449 & 48.038 \\
\hline & & $\mathrm{K}_{1}(\mathrm{~min})^{-1}$ & 0.019 & 0.024 & 0.026 & 0.034 & 0.028 \\
\hline & & $\mathrm{R}^{2}$ & 0.786 & 0.813 & 0.932 & 0.941 & 0.944 \\
\hline
\end{tabular}

Table 2. Compination of pseudo first-order and Pseudo second-order adsorptionrate constant for different initial concentration. 


\begin{tabular}{|c|c|c|c|c|c|c|c|}
\hline & Pseudo second-order & $\begin{array}{l}\text { (mg/g) qe, cal } \\
\mathrm{K}_{2}(\mathrm{~g} /(\mathrm{mg} . \mathrm{min})) \\
\mathrm{R}^{2}\end{array}$ & $\begin{array}{l}12.987 \\
0.1852 \\
0.995\end{array}$ & $\begin{array}{l}21.739 \\
0.01245 \\
0.997\end{array}$ & $\begin{array}{l}45.4545 \\
5.56^{*} 10^{-3} \\
0.997\end{array}$ & $\begin{array}{l}66.667 \\
3.169 * 10^{-3} \\
0.996\end{array}$ & $\begin{array}{l}90.909 \\
2.372 * 10^{-3} \\
0.996\end{array}$ \\
\hline (b) zinc $\left(\mathrm{Zn}^{+2}\right)$ & Pseudo first -order & $\begin{array}{l}\text { parameters } \\
\mathrm{q}_{\mathrm{e}}, \exp (\mathrm{mg} / \mathrm{g}) \\
(\mathrm{mg} / \mathrm{g}) \mathrm{q}_{\mathrm{e}}, \mathrm{cal} \\
\mathrm{K}_{1}(\mathrm{~min})^{-1} \\
\mathrm{R}^{2} \\
(\mathrm{mg} / \mathrm{g}) \mathrm{q}_{\mathrm{e}}, \mathrm{cal} \\
\mathrm{K}_{2}(\mathrm{~g} /(\mathrm{mg} \cdot \mathrm{min})) \\
\mathrm{R}^{2}\end{array}$ & $\begin{array}{l}\text { Concentra } \\
50 \mathrm{mg} / 1 \\
22.00 \\
5.948 \\
0.022 \\
0.638 \\
22.222 \\
1.74 * 10^{-4} \\
0.999\end{array}$ & $\begin{array}{l}(\mathrm{mg} / \mathrm{l}) \\
100 \mathrm{mg} / 1 \\
44.50 \\
14.776 \\
0.025 \\
0.810 \\
45.455 \\
2.178 * 10^{-5} \\
0.999\end{array}$ & $\begin{array}{l}150 \mathrm{mg} / 1 \\
64.00 \\
23.547 \\
0.028 \\
0.872 \\
66.667 \\
8.325 * 10^{-6} \\
0.998\end{array}$ & $\begin{array}{l}200 \mathrm{mg} / 1 \\
84.00 \\
31.563 \\
0.030 \\
0.886 \\
90.909 \\
3.388 * 10^{-6} \\
0.999\end{array}$ & $\begin{array}{l}300 \mathrm{mg} / \mathrm{l} \\
121.50 \\
49.058 \\
0.032 \\
0.910 \\
125.00 \\
1.28 * 10^{-6} \\
0.998\end{array}$ \\
\hline
\end{tabular}

\subsection{Adsorption Isotherm Studies}

\subsubsection{Langmuir Adsorption Isotherm}

Langmuir is the simplest type at theoretical isotherm. Langmuir adsorption isotherm describes quantitatively the formation of monolayer of adsorbate on the outer surface of the adsorbent and after that no further adsorption takes place. Thereby, the Langmuir represents the equilibrium distribution of metal ions between the solid and liquid phases. The Langmuir adsorption is based on the view that every adsorption site is identically and energically equivalent (thermodynamically, each site can hold one adsorbate molecule). The Langmuir isotherm assumes that the ability of molecule to bind and adsorbed is independent of whether or not neighboring site are occupied. This means, there will be no interactions between the adjacent molecules on the surface and immobile adsorption. Also mean, trans-migration of the adsorbate in the plane of the surface is precluded. In this case, the Langmuir isotherm is valid for the dynamic equilibrium (adsorption-desorption) processes on completely homogenous surface with negligible interaction between adsorbed molecules that exhibit the form (39), (40).

$$
\mathrm{C}_{\mathrm{e}} / \mathrm{q}_{\mathrm{e}}=\left[1 /\left(\mathrm{b} * \mathrm{q}_{\max }\right)\right]+\left(\mathrm{C}_{\mathrm{e}} / \mathrm{q}_{\max }\right)
$$

Where $\mathrm{C}_{\mathrm{e}}=$ the equilibrium concentration in solution; $\mathrm{q}_{\mathrm{e}}=$ the amount adsorbed for unit mass of adsorbent; $\mathrm{q}_{\max }=$ the constant related to overall solute absorptivity. In summary, the Langmuir model represents one of the first theoretical treatments of non-linear sorption and suggests the uptake occurs on homogenous surface by monolayer sorption without interaction between adsorbed molecules. The Langmuir isotherm assumes that adsorption sites on the adsorbed surfaces are occupied by the adsorbate in the solution. Therefore, the Langmuir constant (b) represents the degree of adsorption affinity of adsorbate. The maximum adsorption capacity associated with complete monolayer cover is typically expressed in $(\mathrm{mg} / \mathrm{g})$. High values of $\mathrm{b}$ indicate for much stronger affinity of metal ion adsorption. The shape of the isotherm assuming the $(\mathrm{x})$ axis represents the concentration of adsorbing material in the contacting liquid is a gradual positive curve that flattens to a constant value.

A plot of $\mathrm{C}_{\mathrm{e}} / \mathrm{q}_{\mathrm{e}}$ versus $\mathrm{q}_{\mathrm{e}}$ gives a straight line of slope $1 / \mathrm{q}_{\max }$, and intercept $\left(1 /\left(\mathrm{b}^{*} \mathrm{q}_{\max }\right)\right)$ as shown in Figure 16.

The essential features of Langmuir can be expressed in terms of a dimensionless constant separation factor or equilibrium parameter, $\mathrm{R}_{\mathrm{L}}$ that is used to predict if an adsorption system is favorable or unfavorable.

The separation factor, $\mathrm{R}_{\mathrm{L}}$ is defined by $\mathrm{R}_{\mathrm{L}}=\frac{1}{1+\mathrm{bC} 0}$

Where $\mathrm{C}_{0}$ is the initial $\left(\mathrm{Al}^{+3}\right)$ and $\left(\mathrm{Zn}^{+2}\right)$ concentration $(\mathrm{mg}$ /l) and $\mathrm{b}$ is the Langmuir adsorption equilibrium constant $(1 / \mathrm{mg})$.

The parameter indicates the isotherm shape according to $\mathrm{R}_{\mathrm{L}}>1$ is unfavorable, $\mathrm{R}_{\mathrm{L}}=1$ is linear, $0<\mathrm{R}_{\mathrm{L}}<1$ is favorable and $R L=0$ is irreversible. The values of $R L$ are in the range of $(0<\mathrm{RL}<1)$, it indicates that the adsorption of $\left(\mathrm{Al}^{+3}\right)$ and $\left(\mathrm{Zn}^{+2}\right)$ on to activated carbon of apricot stone is favorable. Thus activated carbon of apricot stone is an efficient adsorbent. The value of $\mathrm{R}^{2}$ can give more information about the suitability of adsorption model. Higher values of the correlation coefficient and Freundlich isotherm equation can satisfactorily describe the adsorption of $\left(\mathrm{Al}^{+3}\right)$ and $\left(\mathrm{Zn}^{+2}\right)$ on activated carbon of apricot stone. The adsorption of $\left(\mathrm{Al}^{+3}\right)$ and $\left(\mathrm{Zn}^{+2}\right)$ is shown in Figure 16. The related parameters of the isotherm are presented (Table 3).
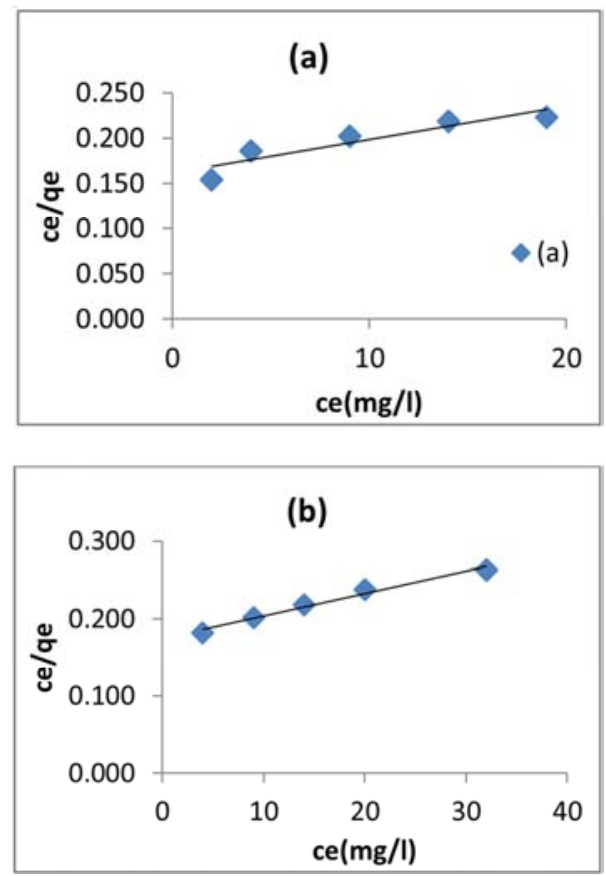

Figure 16. Liner Langmuir adsorption isotherm for (a) Aluminum ions and (b) zinc ions with a activated carbon of apricot stone at $298 \mathrm{~K}$.

\subsubsection{Freundlich Isotherm}

The Freundlich isotherm equation is used for the description 
of multilayer adsorption with the interaction between adsorbed molecules. The model predicts that the adsorbate concentration in the solution will be increasing. The model applies to the adsorption onto heterogeneous surfaces with uniform energy distribution and reversible adsorption. The non-linear form of the Freundlich equation may be written as:

$$
\mathrm{q}_{\mathrm{e}}=\mathrm{k}_{\mathrm{f}}(\mathrm{Ce})^{1 / \mathrm{n}} \text { where } \mathrm{n}>1
$$

The linearized form of Freundlich isotherm given by the equation:

$$
\ln \mathrm{q}_{\mathrm{e}}=\ln \mathrm{K}_{\mathrm{f}}+(1 / \mathrm{n}) \ln \mathrm{Ce}
$$

Where, $\mathrm{q}_{\mathrm{e}}=$ amount adsorbed per unit weight of the adsorbent at equilibrium (mg/ $\mathrm{g}) ; \mathrm{C}_{\mathrm{e}}=$ equilibrium concentration of the adsorbate in solution after adsorption $(\mathrm{mg} / \mathrm{L}) ; \mathrm{K}_{\mathrm{f}}=$ empirical Freundlich constant or capacity factor $(\mathrm{mg} / \mathrm{g}) ; 1 / \mathrm{n}=$ Freundlich exponent. Non-linear behavior of adsorption indicates that adsorption energy barrier increase exponentially with increasing fractional filled sites on the adsorbent. The Freundlich isotherm parameter $(1 / \mathrm{n})$ measures the adsorption intensity of metal ion on adsorbent.

The Freundlich constant $\mathrm{K}_{\mathrm{f}}$ and $\mathrm{n}$ can be obtained by plotting $\operatorname{lnq}_{\mathrm{e}}$ versus $\log \mathrm{C}_{\mathrm{e}}$ as presented in the previous equation. From the plot (Figure 17), the values $\mathrm{K}_{\mathrm{f}}$, and $\mathrm{n}$ can be obtained. Other than the homogenous surface, the Freundlich equations are also suitable for a highly heterogeneous surface and an adsorption isotherm indicates the multi layer adsorption. The value of $1 / \mathrm{n}$ less than unity is an indication that significant adsorption takes place at low concentration but in the increase in the amount adsorbed with concentration become less significant at higher concentration. Thus, the adsorption pattern of metal ions on (ASAC) was well fitted by Langmuir as well as Freundlich isotherm in the experimental concentration range according to the values of correlation coefficient $\mathrm{R}^{2}$. The Langmuir and Freundlich isotherm models provided that the best fit for experimental data which indicated monolayer as well as multilayer adsorption [40-43].
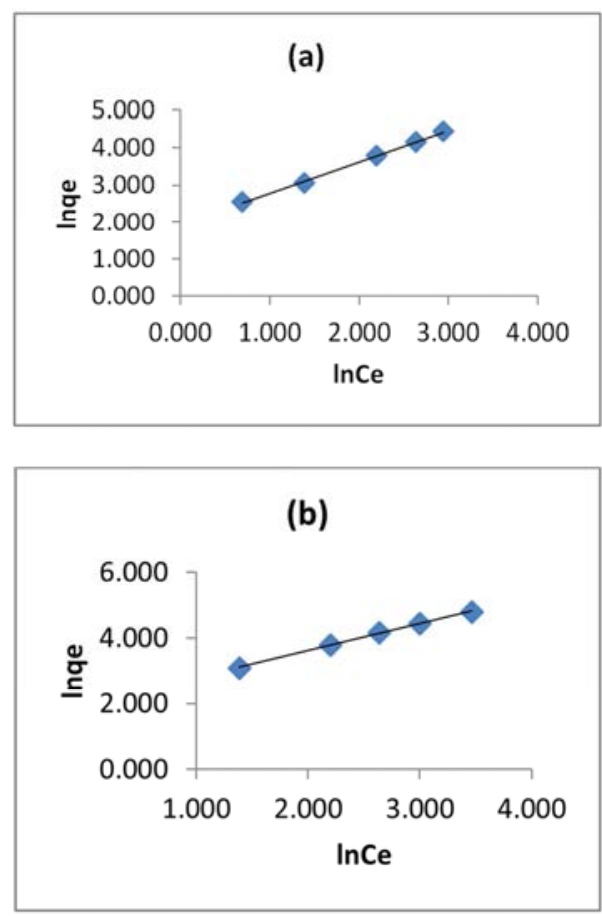

Figure 17. liner Freundlich adsorption isotherm for (a) Aluminum ions and (b) zinc ions with activated carbon of apricot stone at $298 \mathrm{~K}$.

\begin{tabular}{|c|c|c|c|c|c|c|c|c|}
\hline \multirow{7}{*}{ (a) Aluminum ions $\left(\mathrm{Al}^{+3}\right)$} & \multirow{3}{*}{$\mathrm{C}_{0}(\mathrm{mg} / \mathrm{l})$} & \multicolumn{4}{|c|}{ Langmuir isotherm } & \multicolumn{3}{|c|}{ Freundlich isotherm } \\
\hline & & \multirow[t]{3}{*}{$\mathrm{q}_{\max }(\mathrm{mg} / \mathrm{g})$} & \multirow[t]{3}{*}{$\mathrm{b}(1 / \mathrm{mg})$} & \multirow[t]{2}{*}{$\mathrm{R}^{2}$} & \multirow{3}{*}{$\begin{array}{l}\mathrm{R}_{\mathrm{L}} \\
0.642 \\
0.518\end{array}$} & \multirow[t]{3}{*}{$\mathrm{K}_{\mathrm{f}}(\mathrm{l} / \mathrm{g})$} & \multirow[t]{3}{*}{$\mathrm{n}$} & \multirow[t]{2}{*}{$\mathrm{R}^{2}$} \\
\hline & & & & & & & & \\
\hline & 50 & & & & & & & \\
\hline & 100 & 333.3 & 0.0186 & 0.850 & 0.350 & 7.0287 & 1.19189 & 0.998 \\
\hline & 150 & & & & 0.264 & & & \\
\hline & 200 & & & & 0.212 & & & \\
\hline \multirow{7}{*}{ (b) zinc ions $\left(\mathrm{Zn}^{+2}\right)$} & & \multicolumn{2}{|c|}{ Langmuir isotherm } & & & & & \\
\hline & $\mathrm{C}_{0}(\mathrm{mg} / \mathrm{l})$ & $\mathrm{q}_{\max }(\mathrm{mg} / \mathrm{g})$ & B (1/mg) & $\mathrm{R}^{2}$ & $\mathrm{R}_{\mathrm{L}}$ & $\mathrm{K}_{\mathrm{f}}(\mathrm{l} / \mathrm{g})$ & $\mathrm{n}$ & $\mathrm{R}^{2}$ \\
\hline & 50 & & & & 0.637 & & & \\
\hline & 100 & & & & 0.467 & & & \\
\hline & 150 & 500 & 0.0114 & 0.98 & 0.369 & 7.178 & 1.22 & 0.999 \\
\hline & 200 & & & & 0.305 & & & \\
\hline & 300 & & & & 0.226 & & & \\
\hline
\end{tabular}

Table 3. Adsorption isotherm parameters.

\section{Conclusion}

The present investigation showed that waste of apricot stones can be effectively used as a raw material for the preparation of activated carbon for removal of aluminum and zinc ions from aqueous solutions. The adsorption of aluminum and zinc on activated carbon is found to be $\mathrm{pH}$, initial concentration, adsorbent dose and contact time dependent. The adsorption equilibrium was achieved after120 min. The equilibrium data fitted well with the Freundlich isotherm is multi layer adsorption.

The kinetic study of the adsorption of aluminum and zinc ions shows that the pseudo-second order model provides better correlation of the adsorption data. Thermodynamic parameters suggested that the adsorption of aluminum and zinc ions on apricot stone activated carbon was feasible, spontaneous and endothermic in nature.

These results show that ASAC which have a very low economical value may be used effectively for removal of 
aluminum and zinc ions from aqueous solution for environmental protection purpose.

\section{References}

[1] Afkhami A., madrakin T. and Karimi Z. Effect of impregnation of carbon with ethylene diamin tetra aceticacid on its adsorption capacity for the adsorption of several metals ions. J. Hazard. mater., 150:408-412 (2008).

[2] Dean J. G., Bosqui F. L. and Lanouette K. L., Removing heavy metals from wastewater. Environmental Science and Technology, 6, 518 (1972).

[3] Manahan Stanely. E., Environmental Science, Technology, and Chemistry. CRC Press / Lewis Publishers, Boca Raton, FL. (1994).

[4] Kant R. and Kant K. (2010) water pollution: management control and treatment, New Age International, (2010).

[5] Reed B. E. and Nonavinakere S. K., Metal adsorption by activated carbon. Separation Science and Technology, 27, (1985-1992-2000).

[6] Xue Z., Hua Z., Yao, N. and Chen, S., Separation and recovery of nickel and cadmium from spent 12 . Cd-Ni storage batteries and their process wastes. Separation Science and Technology, 27, 213-221 (1992).

[7] Tsezos M. and Volesky B., Biosorption of uranium and Corium. Biotechnology and Bioengineering, 23, 583-604 (1981).

[8] Hohl H. and Stumn W., Interaction of $\mathrm{Pb}+2$ with anhydrous Al203. J. Colloid Interface Sci, 55, 281-288, (1976).

[9] Doina A., Laura B., Elena B., Lead (II) removal from aqueous solutions by adsorption onto chitosan, Cellul. Chem. Technol., 43, 211-216 (2009).

[10] Oladoja N. A., Aboluwoye Oladimeji Y. B., Kinetics and Isotherm studies on methylene blue adsorption onto ground palm kernel coat, Turkish J. Eng. Env. Sci., 32, 303-312 (2008).

[11] Yahya S., Musa I., Amjad H., Gavin M., Effect of solution pH, ionic strength, and temperature on adsorption behavior of reactive dyes on activated carbon, Dyes and Pigments, 20, 1-8 (2007).

[12] Nikam G. H. and Mohite B. S., Liquid-Liquid extraction and separation of Cobalt (II) from sodium acetate media using Cyanex 272, Res. J. chem. Sci., 2, 75-82 (2012)

[13] Nandkumar D. V. and Lawrence T. L., Zinc, Cadmium and Lead Separation from aqueous streams using solid - phase extract ants, Ind. Eng. Chem. V, 36, 399-406 (1997).

[14] Vedula R. K. and Balomajumder C., Simultaneous Adsorptive Removal of Cyanide and Phenol from Industrial Wastewater: Optimization of Process Parameters, Res. J. chem. sci., 1, 3039 (2011).

[15] Nirmal Kumar J. I., Cini 0., Removal of heavy metals by biosorption using fresh water alga Spirogyra hyaline,. 1. Environ. Biol., 33, 27-31 (2012).

[16] Kadirvelu K., Kavipriya M., Karthika C., Radhika M., Vennilamani N., Pattabhi S., Utilization of various agricultural wastes for activated carbon preparation and application for the removal of dyes and metal ions from aqueous solutions, Bioresour. Technol., 87, 129-132 (2003).

[17] Murhekar G. H., Assessment of Physico-Chemical Status of Ground Water Samples in Akot city Research Journal Of ChemicalSciences, 1 (4), 117-124 (2011).

[18] Shabudeen P. S. S., Study of the Removal of Malachite Green from Aqueous Solution by using Solid Agricultural Waste, Res. J. chem. sci., 1, 88-104 (2011).

[19] Vengris T., Binkiene R., Sveikauskaite A., Nickel, Copper and Zinc removal from wastewater by a modified clay sorbent, Appl. Clay Sci., 18, 183-190 (2001).

[20] Newton D. F. L., Adsorption of Copper (11) and Cobalt (II) Complexes on a silica gel surface chemically modified with 3amino-1, 2, 4-triazole, Colloids Surf., 144, 219 -227 (1998).

[21] Meenakshi G., Rattan V. K., Bansal R. C., Removal of Copper from aqueous solutions by adsorption on activated carbons, Colloids Surf, A, 190, 229-230 (2001).

[22] Gottipatti R. and Mishra S., Application of Response surface Methodology for Optimization of $\mathrm{Cr}$ (III) and $\mathrm{Cr}$ (VI) Adsorption on Commercial Activated carbons, Res. J. chem. sci., 2, 40-48 (2012).

[23] Bin Y., Alka S., Shyam SS., Kenneth D. L., The Removal of heavy metal from aqueous solutions by sawdust adsorption Removal of copper, J. Hazard. Mater., 80, 33-42 (2000).

[24] Njoku VO, Hameed BH. Preparation and characterization of activated carbon from corncob by chemical activation with $\mathrm{H}_{3} \mathrm{PO}_{4}$ for 2, 4-dichlorophenoxyacetic acid adsorption.

[25] Smith B. C. infrared spectral interpretation: A Systematic Approach. CRC Press. Boca Raton; 1999.

[26] Ren, L., Zhang, J., Li, Y. \& Zhang, C. Preparation and evaluation of cattail fibre-based activated carbon for 2, 4dichlorophenol and 2, 4, 6-trichlorophenol removal, Chem. Eng. J., 168, 553-561 (2011).

[27] Förstner, U. and Wittman, G. T. W. Metal Pollution in the Aquatic Environment. 2nd Edition, Springer-Verlag, Berlin, German (1981)

[28] Gueu S., Yao B., Adouby K. and Ado G., Int. J. Environ. Sci. Technol., 4, 11 (2007).

[29] Horsfall M. andAbia A., Water Res., 37, 4913 (2003).

[30] Dakiky M., Kharnis M. and Manassra A., Adv. Environ. Res., 6, 533 (2002).

[31] Acar F. N. and Eren Z., Hazard J. Mater, 137, 909 (2006).

[32] Bulut Y. and Tez Z., Environ J., Sci., 19, 160 (2007).

[33] Caramalau C., Bulgariu L. and Macoveanu M., Cheat. Bull. "POLITEHNICA". (Tindsoara), 54, 13 (2009).

[34] Ramiro J. E. M., Rosano P., Rui A. R. B., Cadmium (I1) and Zinc (U) adsorption by the aquatic moss Fontinalis antipyretics: effect of temperature, $\mathrm{pH}$ and water hardness, Water Res., 38, 693-699 (2004).

[35] Aksu Z. and Kutsat T. A., J. Chem. Technol. Biotechnol., 52, 109 (1991). 
[36] Horsfall Jnr. M and Spiff. A. T., Electron. J. Biotechnol., 8, $162(2005)$.

[37] Gupta. V. K., Srivastava. S. K. and Mohan. D. Ind. Eng. Chem. Res., 36, 2207 (1997).

[38] Lagergren. S, Vetenskapsakad Handl. Svenska. K. 24No 4 (1998).

[39] Ho and Mckay G., Can. J Chem. Eng., 76, 822 (1998).

[40] Hall K. R, Eagleton. L. C., Acrivos. A and Vermeulen T., Ind. Eng. Chem. Furzdam., 5, 212 (1966).
[41] Prabakaran R. andArivoli S., Eur. J. Appl. Eng. Sci. Res., 1,134 (2014).

[42] Arivoli J. S, Martin Deva Prasath P. and Thenkuzhali M., EJEAFChe, 6, 2323 (2007).

[43] Singh S., Verma L. K., Sambi S. S. And Sharma S. K. Proceeding of the World Congress on Engineering and Computer Science (WCECS 2008), Sanfrancisco, USA, October 22-24 (2008). 